\title{
DIALEKTIKA ISLAM DAN BUDAYA LOKAL JAWA
}

\author{
Andik Wahyun Muqoyyidin \\ Universitas Pesantren Tinggi Darul 'Ulum Jombang \\ Komplek PP. Darul Ulum Peterongan Jombang 61481 \\ E-mail: andikwahyun_m@yahoo.com \\ HP. +62-82139699764
}

Abstract: This article reveals the Islamic cultural problems which spreads and develops in Indonesia especially those which are related to Islam and Javanese culture dialectic. This idea refers to cultural-sociological frame which dominated more in the form of acculturation. Although there was a fluctuated development in the 19's still acculturation dominated almost all religion's expression in Java. Syncretism and religion tolerance became the character of Islam in Java and this was based to Javanese context animism and Hinduism.

Abstrak: Tulisan ini berusaha mengurai persoalan dinamika Islam kultural yang ada, tumbuh, dan berkembang di Indonesia, khususnya yang terkait dialektika antara Islam dan budaya lokal Jawa. Pemikiran ini mengacu pada kerangka sosiologi budaya. Penyebaran Islam di Jawa, lebih dominan mengambil bentuk akulturasi, baik yang bersifat menyerap maupun dialogis. Kendati ada fluktuasi relasi Islam dengan Budaya Jawa terutama era abad ke 19-an, namun wajah Islam Jawa yang akulturatif terlihat dominan dalam hampir setiap ekspresi keberagamaan masyarakat muslim di wilayah ini, sehingga "sinkretisme" dan toleransi agama-agama menjadi satu watak budaya yang khas bagi Islam Jawa. Konteks Jawa yang melatari munculnya Islam di Jawa adalah animisme dan hinduisme, maka logis jika "warna dan citarasa" Islam yang berkembang di Jawa juga bernuansa animisme dan hinduisme.

Kata Kunci: Budaya Islam, Dialektika Islam, Budaya Lokal, Islam Jawa, Sinkretisme.

\section{A. Pendahuluan}

Islam datang, berkembang dan melembaga di Nusantara melalui proses yang panjang. Sejauh ini, teori yang diajukan para pakar mengenai masuknya Islam ke Nusantara bisa dikelompokkan menjadi tiga macam. Pertama, teori 
yang mengatakan bahwa asal-usul Islam di Nusantara adalah dari Anak Benua India; dan bukan dari Persia atau Arabia. Teori ini kemudian terkenal disebut teori India. Sarjana pertama yang mengatakan teori ini adalah Pijnappel, seorang pakar dari Universitas Leiden, Belanda. Pijnappel mengaitkan asal-mula Islam di Nusantara dengan wilayah Gujarat dan Malabar. Menurut dia, pembawa Islam ke Nusantara adalah orang-orang Arab bermadzhab Syafi'i yang bermigrasi dan menetap di wilayah India. Teori Pijnappel ini kemudian diamini dan dikembangkan oleh sarjana-sarjana lain yang juga berasal dari Belanda, seperti Snouck Hurgronje, Fatimi, Vlekke, Gonda, Schrieke, dan Moquette.

Kedua, teori yang mengemukakan bahwa asal-usul Islam di Nusantara berasal dari Arab dan/ atau Timur Tengah. Para pakar sejarah yang mendukung teori ini, di antaranya: Arnold, Marrison, Crawford, Keijzer, Neimann, Hollander, dan Naquib Al-Attas. Keijzer, misalnya, memandang bahwa Islam di Nusantara berasal dari Mesir atas dasar pertimbangan kesamaan kepemelukan penduduk Muslim di kedua wilayah kepada madzhab Syafi'i (Azra, 2004: 2-17).

Baru belakangan muncul dugaan bahwa asal-usul Islam di Nusantara bukan dari India atau dari Timur Tengah, melainkan dari Cina. Selanjutnya, memosisikan dugaan ini sebagai teori ketiga (Romdhoni, 2008: 95). Menurut teori ketiga ini, komunitas Cina-muslim telah memberikan kontribusi yang cukup besar at as berkembangnya Islam di Nusantara, khususnya Jawa. Eksistensi Cina-muslim pada awal perkembangan Islam di Jawa tidak hanya ditunjukkan oleh kesaksian para pengelana asing, sumber-sumber Cina, teks lokal Jawa maupun tradisi lisan saja, tetapi juga didukung peninggalan-peninggalan purbakala Islam di Jawa. Misalnya, ukiran padas di masjid kuno MantinganJepara, menara masjid pecinan Banten, konstruksi pintu makam Sunan Giri di Gresik, arsitektur keraton Cirebon beserta taman Sunyaragi, konstruksi masjid Demak, terutama soko tatal penyangga masjid beserta lambang kura-kura, konstruksi masjid Sekayu di Semarang dan sebagainya, semuanya menunjukkan pengaruh budaya Cina yang cukup kuat. Bukti lain adalah dua bangunan masjid yang berdiri megah di Jakarta, yakni masjid Kali Angke yang dihubungkan dengan Gouw Tjay dan Masjid Kebun Jeruk yang didirikan oleh Tamien Dosol Seeng dan Nyonya Cai (al-Qurtuby, 2003).

Islam yang berdialektika dengan budaya lokal tersebut pada akhirnya membentuk sebuah varian Islam yang khas dan unik, seperti Islam Jawa, Islam Madura, Islam Sasak, Islam Minang, Islam Sunda, dan seterusnya. Varian Islam tersebut bukanlah Islam yang tercerabut dari akar kemurniannya, tapi Islam yang di dalamnya telah berakulturasi dengan budaya lokal. Dalam istilah lain, telah terjadi inkulturasi. Dalam studi kebudayaan lokal, inkulturasi meng- 
andaikan sebuah proses internalisasi sebuah ajaran baru ke dalam konteks kebudayaan lokal dalam bentuk akomodasi atau adaptasi. Inkulturasi dilakukan dalam rangka mempertahankan identitas. Dengan demikian, Islam tetap tidak tercerabut akar ideologisnya, demikian pun dengan budaya lokal tidak lantas hilang dengan masuknya Islam di dalamnya (Paisun, 2010: 156).

Varian Islam lokal tersebut, untuk selanjutnya menyebutnya Islam kultural terus lestari dan mengalami perkembangan di berbagai sisi. Islam kultural tetap menjadi ciri khas dari fenomena keislaman masyarakat Indonesia yang berbeda dengan Islam yang ada di Timur Tengah, maupun Eropa. Hal ini tidak lepas dari heterogenitas dan kemajemukan bangsa Indonesia yang tidak dimiliki oleh bangsa mana pun di dunia. Sebagaimana mafhum, Indonesia sebagai negara plural, tidak hanya beragam dari segi agama, keyakinan, budaya, suku bangsa dan juga bahasa. Negeri ini juga multietnik (Dayak, Kutai, Banjar, Makassar, Bugis, Jawa, Madura, Sunda, Batak, Aceh, Minang, Flores, Bali dan seterusnya) dan juga menjadi medan pertarungan berbagai pengaruh multimental dan ideologi (India, Cina, Belanda, Portugis, Hinduisme, Buddhisme, Konfuisme, Islam, Kristen, Kapitalisme, Sosialisme, dan seterusnya) (Aziz, 2009 dalam Paisun, 2010: 156). Heterogenitas dan kemajemukan bangsa tersebut pada gilirannya menempatkan Indonesia sebagai negara yang unik, khas, dan menarik. Demikian pun dengan pola keberagamaan yang dianutnya. Agama yang tumbuh dan berkembang di Indonesia mau tidak mau harus berdialektika dengan budaya lokal yang kemudian mempunyai ciri khas dan keunikan tersendiri.

Sebagai salah satu varian Islam kultural yang ada di Indonesia setelah terjadinya dialektika antara Islam dengan budaya Jawa, Islam Jawa memiliki karakter dan ekspresi keberagamaan yang unik. Hal ini karena penyebaran Islam di Jawa lebih dominan mengambil bentuk akulturasi, baik yang bersifat menyerap maupun dialogis. Pola akulturasi Islam dan budaya Jawa, di samping bisa dilihat pada ekspresi masyarakat Jawa, juga didukung dengan kekuasaan politik kerajaan Islam Jawa, terutama Mataram yang berhasil mempertemukan Islam Jawa dengan kosmologi Hinduisme dan Buddhisme. Kendati ada fluktuasi relasi Islam dengan budaya Jawa terutama era abad ke 19-an, namun wajah Islam Jawa yang akulturatif terlihat dominan dalam hampir setiap ekspresi keberagamaan masyarakat muslim di wilayah ini sehingga "sinkretisme" dan toleransi agama-agama menjadi satu watak budaya yang khas bagi Islam Jawa (Sumbulah, 2012: 51).

Kenyataannya, Islam di Jawa memang tidak bersifat tunggal, tidak monolit, dan tidak simpel. Islam Jawa bergelut dengan kenyataan negara- 
bangsa, modernitas, globalisasi, kebudayaan lokal, dan semua wacana kontemporer yang menghampiri perkembangan zaman dewasa ini. Dalam konteks ini, respon kelompok-kelompok atau organisasi-organisasi Islam di Indonesia dan Jawa khususnya sangat variatif, mulai dari konservatif, moderat, liberal, radikal, hingga fundamentalis (Muqoyyidin, 2012: 20). Tulisan ini secara spesifik dimaksudkan mengkaji dinamika Islam kultural yang ada, tumbuh, dan berkembang di Indonesia, khususnya yang terkait dialektika antara Islam dan budaya lokal Jawa.

\section{B. Diskursus Agama dan Budaya}

“... all religion as "an effort to conceive the inconceivable and to express the inexpreesible, an aspiration to ward the infinite" (Durkheim, 1995: 23). Kodrat sebagai manusia memiliki pengetahuan dan daya nalar yang terbatas. Keterbatasan itu memaksa manusia unt uk mengakui dan menerima hal-hal yang di luar jangkauannya. Atas dasar keterbatasan tersebut, lahirlah agama atau kepercayaan tertentu yang dikatakan sebagai ekspresi ketidakmampuan manusia untuk menangkap atau menerangkan dengan akal pikiran gejala-gejala yang ada di sekitarnya. Pada sisi yang lain, agama juga bisa muncul sebagai akibat adanya krisis-krisis yang membuat gelisah dalam kehidupan manusia. Mereka ingin kegelisahan itu hilang dan menemukan jawaban untuknya dalam agama (Koentjaraningrat, 1994: 237).

Adapun hal-hal yang mendorong manusia untuk melaksanakan aktivitasaktivitas yang bersifat keagamaan karena adanya emosi dan getaran jiwa yang sangat mendalam yang disebabkan sikap takut, terpesona pada sesuatu yang gaib dan keramat. Selain itu, juga adanya harapan-harapan yang mengiringi perjalanan kehidupannya. Perasaan-perasaan itu terpancar dari daya misterius yang merupakan prinsip kesatuan alam semesta (Kholil, 2009: 86).

Lebih lanjut, makna agama dalam The Encyclopedia of Phylosophy pada entri religi ada beberapa, di antaranya (Durkheim, 1995: 7): Agama menurut Martineau adalah kepercayaan kepada Tuhan yang selalu hidup, yakni kepada jiwa dan kehendak Ilahi yang mengatur alam semesta dan mempunyai hubungan moral dengan umat manusia. Agama adalah pengakuan bahwa segala sesuatu merupakan manifestasi dari Kuasa yang melampaui pengetahuan kita. Seperti yang tertulis di atas, pembicaraan atau pemaknaan mengenai agama berputar pada persoalan Tuhan dan ketuhanan, dan kata ini oleh para pengamat keagamaan, agar bisa merangkum semua jenis kepercayaan masyarakat yang lazimnya disebut agama diganti dengan "Kuasa yang Transenden", Kuasakuasa di atas manusia, "Sesuatu yang di luar", "Realitas Transenden", "Realitas 
Supranatural". Pembahasan tentang Tuhan atau konsep-konsep lain yang berhubungan dengan tema-tema keilahian biasanya disebut teologi. Namun demikian, tidak semua agama memiliki konsep tersebut (Kholil, 2009: 87).

Sementara itu, menurut Canadian Commission for Unesco (1977: 83) kebudayaan dinyatakan sebagai: A dynamic value system of learned elements, with asumptions, conventions, beliefs and rules permitting members of a group to relate to each other and to the world, to communicate and to develop their creative potential. Ada elemen penting di dalam definisi di atas, bahwa kebudayaan adalah sebuah sistem nilai yang dinamik dari elemen-elemen pembelajaran yang berisi asumsi, kesepakatan, keyakinan dan aturan-aturan yang memperbolehkan anggota kelompok untuk berhubungan dengan yang lain. Pengertian kebudayaan ini termasuk di dalam pengertian kebudayaan sebagai sistem nilai, yaitu kebudayaan sebagai sistem normatif yang mengat ur kehidupan bermasyarakat (Syam, 2005: 13).

Pengertian kebudayaan di at as berbeda dengan perspektif strukturalisme yang memandang kebudayaan sebagai produk atau hasil dari aktivitas nalar manusia. Ia memiliki kesejajaran dengan bahasa yang juga merupakan produk dari aktivitas nalar manusia. Sumber kebudayaan tak lain adalah nalar manusia atau human mind (Ahimsa-Putra, 1999: 23-25).

Pengertian ini hampir sama dengan perspektif antropologi kognitif, yang melihat kebudayaan sebagai sesuatu yang berada di kepala-kepala individu dan bukan sesuatu yang shared di masyarakat atau kebudayaan sebagai kognisi manusia. Mengutip Goodenough dia menyatakan:

"Kebudayaan suatu masyarakat terdiri dari apa-apa yang harus diketahui atau dipercayai untuk dapat berfungsi sedemikian rupa sehingga dianggap pantas oleh anggota-anggotanya. Kebudayaan bukanlah fenomena material, tidak terdiri dari benda-benda, perilaku dan emosi. Ia lebih merupakan suatu pengaturan hal-hal itu. Yang ada dalam pikiran orang adalah bentuk-bentuk benda dan hal-hal, model-model untuk mempersepsi, menghubung-hubungkan, dan selebihnya menafsirkan" (Oetomo, 2000: 3).

Kebudayaan ialah:

"keseluruhan pengetahuan yang dipunyai oleh manusia sebagai makhluk sosial, yang isinya adalah perangkat-perangkat, model-model pengetahuan yang secara selektif dapat digunakan untuk memahami dan menginterpretasikan lingkungan yang dihadapi dan untuk mendorong dan menciptakan tindakan-tindakan yang diperlukannya" (Suparlan, 1986: 107).

Pengertian kebudayaan di atas berbeda dengan pengertian kebudayaan dalam perspektif evolusionistik, yaitu kebudayaan merupakan cipta, rasa dan 
karsa manusia atau kelakuan dan hasil kelakuan. Kebudayaan mengandung tiga hal utama, yaitu sebagai sistem budaya yang berisi gagasan, pikiran, konsep, nilai-nilai, norma, pandangan, undang-undang dan sebagainya yang berbentuk abstrak, yang dimiliki oleh pemangku ide. Sistem budaya it u yang disebut sebagai "tata budaya kelakuan". Kebudayaan sebagai aktivitas para pelaku budaya seperti tingkah laku berpola, upacara-upacara yang wujudnya konkret dan dapat diamati yang disebut sebagai sistem sosial yang berwujud "kelakuan". Kebudayaan yang berwujud benda-benda, baik hasil karya manusia atau hasil tingkah lakunya yang berupa benda atau disebut "hasil karya kelakuan" (Koentjaraningrat, 1985 dan Soekiman, 2000: 40-41).

Mengikuti pendapat Keesing (1975) dan Sperber $(1975,1985)$ menyatakan kebudayaan ialah "suatu sistem pengetahuan sadar dan di luar sadar yang berada di dalam pikiran individu. Sistem pengetahuan kebudayaan tersebut diorganisir secara hierarkis" (Woodward, 2000: 69). Di dalam pengetahuan kebudayaan terdapat pengetahuan yang umum dan khusus (kontekstual). Asumsi yang lebih umum tersebut disebut sebagai aksioma pengetahuan budaya. Oleh karena itu, di dalam tulisannya mengenai Islam Jawa, Woodward memperkenalkan konsep dan pendekatan baru di dalam hubungan antara agama dan budaya ialah aksiomatika struktural. Aksiomatika terkait dengan landasan teks-teks yang menjadi pegangan atau mendasari paham keagamaan, dan di sisi lain, struktur terkait dengan konteks sosio-religio-kultural di mana teks tersebut dipahami dan menjadi basis bagi proses pembentukannya. Melalui kajiannya ini diperoleh suat u teoretisasi "konsep-konsep keagamaan dapat menjadi basis bagi pembentukan struktur sosial, ekonomi dan bahkan politik".

Melalui pendefinisian kebudayaan seperti itu akan memungkinkan agama dapat dikaji. Agama bukanlah wujud dari gagasan atau produk pemikiran manusia atau kelakuan atau hasil kelakuan. Definisi kebudayaan sebagai kelakuan dan hasil kelakuan manusia tidaklah dapat digunakan karena kelakuan dan hasil kelakuan adalah produk kebudayaan. Agama bukan semata-mata produk kelakuan atau hasil kelakuan. Pengertian strukturalisme mengenai kebudayaan juga kurang tepat untuk melihat agama, sebab agama bukan hanya sebagai produk kognitif. Oleh karena itu, digunakanlah pandangan atau perspektif yang melihat agama sebagai sistem kebudayaan (Syam, 2005: 16).

Menanggapi agama sebagai sistem kebudayaan, Suparlan menyatakan bahwa pada hakikatnya agama adalah sama dengan kebudayaan, yaitu suatu sistem simbol atau suatu sistem pengetahuan yang menciptakan, menggolonggolongkan, meramu atau merangkaikan dan menggunakan simbol untuk berkomunikasi dan untuk menghadapi lingkungannya. Namun demikian, ada 
perbedaannya bahwa simbol di dalam agama adalah simbol suci (Suparlan, 1986: 87).

Lebih eksplisit dari itu, Geertz juga memahami agama sebagai sistem kebudayaan (Syam, 2007: 11-13). Kebudayaan, dalam pandangan Geertz didefinisikan sebagai pola bagi kelakuan yang terdiri dari serangkaian aturanat uran, resep-resep, rencana-rencana dan petunjuk-petunjuk yang digunakan manusia untuk mengatur tingkah lakunya. Kebudayaan dengan demikian juga dilihat sebagai pengorganisasian pengertian-pengertian yang tersimpul dalam simbol-simbol yang berkaitan dengan ekspresi manusia (al-Humaydi, 2007: 278). Karena itu, Geertz kemudian memahami agama tidak saja sebagai seperangkat nilai di luar manusia, tapi juga merupakan sistem pengetahuan dan sistem simbol yang memungkinkan terjadinya pemaknaan (Syam, 2007: 13).

Sebagai sebuah kenyataan sejarah, agama, dan kebudayaan dapat saling memengaruhi karena keduanya memiliki nilai dan simbol. Agama adalah simbol yang melambangkan nilai ketaatan kepada Tuhan. Kebudayaan juga mengandung nilai dan simbol supaya manusia bisa hidup di dalamnya. Agama memerlukan sistem simbol. Dengan kata lain, agama memerlukan kebudayaan. Namun keduanya perlu dibedakan. Agama adalah sesuatu yang final, universal, abadi, dan tidak mengenal perubahan (absolut). Kebudayaan bersifat partikular, relatif, dan temporer. Agama tanpa kebudayaan memang dapat berkembang sebagai agama pribadi. Namun, tanpa kebudayaan, agama sebagai kolektivitas tidak akan mendapat tempat (Kuntowijoyo, 2001: 196).

Agama dan kebudayaan mempunyai dua persamaan: pertama, keduanya adalah sistem nilai dan sistem simbol, dan kedua, baik agama maupun kebudayaan mudah sekali terancam setiap kali ada perubahan. Agama dalam perspektif ilmu-ilmu sosial adalah sistem nilai yang memuat sejumlah konsepsi mengenai konstruksi realitas, yang berperan besar dalam menjelaskan struktur tata normatif dan tata sosial serta memahamkan dan menafsirkan dunia sekitar. Sementara itu, kebudayaan merupakan ekspresi cipta, karya, dan karsa manusia (dalam masyarakat tertentu) yang berisi nilai-nilai dan pesan-pesan religiositas, wawasan filosofis, dan kearifan lokal (local wisdom) (Riyadi, 2003 dalam Shulhan, 2012: 177).

Sebagai sistem pengetahuan, agama merupakan sistem keyakinan yang sarat dengan ajaran-ajaran moral dan petunjuk kehidupan (baca: Wahyu) yang harus dipelajari, ditelaah, dan dipraktikkan oleh manusia dalam kehidupannya. Dalam hal ini, agama memberikan petunjuk mengenai yang baik dan buruk, yang pantas dan tidak pantas, dan yang tepat dan tidak tepat. Nilai-nilai agama 
dapat membentuk dan mengkonstrukkan perilaku manusia dalam kesehariannya (Paisun, 2010: 158).

Dalam agama sebagai sistem simbol, terdapat simbol-simbol tertentu untuk mengaktualisasikan ajaran agama yang dianutnya. Simbol-simbol yang dimaksud berupa perbuatan, kata-kata, benda, sastra, dan sebagainya. Sujud misalnya, merupakan sebentuk simbolisasi at as kepasrahan dan penghambaan penganutnya pada pencipta. Sujud merupakan simbol totalitas kepasrahan hamba, dan pengakuan secara sadar akan kemahabesaran Allah SWT. Dalam hal ini, sujud yang terdapat dalam shalat merupakan bagian dari ritual keagamaan dalam kehidupan masyarakat beragama (al-Humaidy, 2007: 282-284).

Ajaran Islam yang termuat di dalam teks al-Qur'an dan al-Hadis adalah ajaran yang merupakan sumber asasi, dan ketika sumber itu digunakan atau diamalkan di suatu wilayah — sebagai pedoman kehidupan — maka bersamaan dengan itu, tradisi setempat bisa saja mewarnai penafsiran masyarakat lokalnya. Oleh karena penafsiran itu bersentuhan dengan teks suci, maka simbol yang diwujudkannya juga merupakan sesuatu yang sakral. Setiap tradisi keagamaan memuat simbol-simbol suci yang dengannya orang melakukan serangkaian tindakan untuk menumpahkan keyakinan dalam bentuk melakukan ritual, penghormatan, dan penghambaan. Salah satu contoh ialah melakukan upacara lingkaran hidup dan upacara intensifikasi, baik yang memiliki sumber asasi di dalam ajaran agama atau yang dianggap tidak memiliki sumber asasi di dalam ajaran agama.

Tradisi keagamaan yang bersumber dari ajaran agama disebut Islam Offisial atau Islam Murni, sedangkan yang dianggap tidak memiliki sumber asasi di dalam ajaran agama disebut Islam Popular atau Islam Rakyat (Syam, 2007: 13) at au juga Islam Kultural dalam terminologi Gus Dur. Pembacaan terhadap Islam di Indonesia dengan menggunakan kerangka pemahaman seperti di atas, tidak saja akan menemukan keterkaitan historis dengan realitas kesejarahan Islam, tetapi juga akan menemukan satu sisi penting dari awal proses transformasi intelektual Islam yang bertolak dari nilai-nilai universalisme Islam yang dikategorikan sebagai tradisi besar dengan tata nilai dalam setting kultural dan struktural tertentu yang sudah terpola sebelumnya (Ridwan, 2008: 1).

\section{Relasi Akomodasionis Islam dengan Budaya Lokal}

Persoalan agama dan budaya adalah salah satu persoalan krusial yang melahirkan berbagai penilaian dalam masyarakat. Dialektika agama dan budaya di mata masyarakat muslim secara umum banyak melahirkan penilaian subjektif-pejoratif. Sebagian bersemangat untuk mensterilkan agama dari 
kemungkinan akulturasi budaya setempat, sementara yang lain sibuk dan fokus membangun pola dialektika antarkeduanya (Roibin, 2010: 1).

Terlepas keyakinan masing-masing pemahaman, dalam faktanya, potret keberagamaan semakin menunjukkan suburnya pola akulturasi, bahkan sinkretisasi lintas agama. Indikasi terjadinya proses dialektika antara agama dan budaya tersebut, dalam Islam terlihat pada fenomena perubahan pola pemahaman keagamaan dan perilaku keberagamaan dari tradisi Islam murni (high tradition) misalnya, melahirkan berbagai corak Islam lokal, antara lain Islam Sunni, Islam Syi'i, Islam Mu'tazili, dan Islam Khawarij (low tradition) (Abdullah, 2001: iii; Ridwan, 2004: 129-136; dan Tibi, 1991: 8).

Pembacaan dalam perspektif sosiologis terhadap fenomena bahwa Islam hadir dan berdialektika dengan tradisi menunjukkan bahwa Islam merupakan respons atas kondisi yang bersifat khusus di tanah Arab. Dalam konteks ini, terdapat beberapa kondisi yang pat ut disadari. Pertama, Islam itu sendiri sebenarnya lahir sebagai produk lokal yang kemudian diuniversalisasi dan ditransendensikan sehingga menjadi Islam universal (Bizawie, 2003: 33-34). Yang dimaksud Islam sebagai produk lokal adalah Islam yang lahir di Arab (Hijaz), dalam situasi Arab dan ditujukan sebagai jawaban terhadap persoalanpersoalan yang berkembang di sana. Kedua, seberapapun diyakini bahwa Islam itu wahyu Tuhan yang universal, pada akhirnya dipandang oleh pemeluk sesuai dengan pengalaman, problem, kapasitas intelektual, sistem budaya dan segala keragaman setiap pemeluk di dalam komunitasnya. Dengan kata lain, aktualisasi Islam dalam sejarah, telah menjadikan Islam tidak dapat dilepaskan dari aspek lokalitas, mulai dari Arab, Persia, Turki, India, sampai Asia Tenggara, masing-masing sesuai dengan karakteristiknya sendiri (Abadi dan Susanto, 2012: 229).

Karena itu, ketika Islam berkembang, ia tidak akan pernah betul-betul sama dari satu tempat ke tempat lainnya atau dari suatu waktu ke waktu lainnya. Secara historis, Islam dan pandangan-pandangan yang terkait dengannya membentuk sebuah tradisi kultural, atau sebuah kompleks tradisi-tradisi. Sebuah tradisi kultural tersebut dengan sendirinya tumbuh dan berubah, semakin luas lingkupnya (Hodgson, 2002: 112). Perspektif demikian, diidentifikasi sebagai perspektif akomodasionis (Abadi dan Susanto, 2012: 229).

Perspektif akomodasionis pada gilirannya akan mengantarkan pada pemahaman bahwa relasi Islam dengan budaya lokal berlangsung dalam konstruksi apresiatif-akomodatif-afirmatif sehingga akan menampilkan wajah tradisi Islam yang beragam. Dalam perspektif ini, pembicaraan tentang prosesproses enkulturasi dan akulturasi terhadap tradisi kultural setempat berjalan 
dalam bentuknya yang bervariasi, dan sejarah telah membuktikan bahwa tidak ada bentuk tradisi kultural keislaman yang tunggal.

Perspektif akomodasionis ini telah dilaksanakan secara amat berhasil oleh Walisongo. Mereka berusaha memperkenalkan Islam melalui jalur tradisi sehingga mereka perlu mempelajari kearifan lokal. Dari sinilah, kemudian lahir berbagai serat atau kitab. Wayang yang merupakan bagian ritual dan seremonial Agama Hindu bisa diubah menjadi sarana dakwah dan pengenalan ajaran monoteis. Ini adalah sebuah kreativitas yang sedemikian canggih sehingga seluruh warga masyarakat dalam semua lapisan strata sosial, petani, pedagang dan bangsawan diislamkan melalui jalur ini. Mereka merasa aman dengan hadirnya Islam karena ia hadir tanpa mengancam tradisi, budaya dan posisi mereka (Mun'im DZ, 2008: 4).

Dengan bertitik pijak pada paradigma ini, beberapa konstruksi teoretis para ilmuwan tentang Islam Indonesia-dan praktik keislaman pada komunitas Muslim lainnya - yang dipandang sebagai sekadar Islam nominalis, menjadi terkoreksi (Abadi dan Susanto, 2012: 230). "Islam lokal, yang selama ini menurut beberapa pengamat dipandang sebagai bukan Islam yang sesungguhnya, melainkan sebatas Islamisasi di permukaan saja" (Bruinessen, 2003: 69) menjadi terbantahkan.

Demikian pula pandangan bahwa "Praktik keagamaan orang Indonesia lebih banyak terpengaruh oleh agama India (Hindu dan Buddha) yang telah lama hidup di wilayah kepulauan Nusantara, bahkan dipengaruhi agama-agama penduduk asli dengan memuja nenek moyang dan roh-roh halus," dinilai sebuah perspektif yang "salah" pijak. Konsep yang ditelurkan oleh Redfield sebagai "tradisi besar" dan "tradisi kecil" yang banyak digunakan dalam studi antropologi pada masyarakat dunia ketiga, juga menjadi kurang relevan.

Implikasi perspektif tersebut telah melahirkan corak Islam yang dinamis, beragam, terbuka, toleran, dan moderat sehingga sangat kondusif bagi tumbuh suburnya wacana kebudayaan sebagai hasil "negosiasi konstruktif" (constructive negotiation) yang terus berlangsung sehingga apa-apa yang dilakukan oleh generasi awal (salaf) tidak menjadi kemestian dan keharusan bagi generasi saat ini, yang hidup dalam waktu dan tempat yang berbeda. Generasi saat ini hanya terkena tanggung jawab untuk menerapkan nilai-nilai terdalam dari Islam (Islam substantif). Karena itu, apresiasi terhadap tradisi, budaya, struktur sosial dan kondisi masyarakat sangat diperlukan untuk merumuskan sebuah sistem yang pas, yang memenuhi cita terdalam dari pesan Islam. Akan tetapi, pada sisi lain, tetap memenuhi prasyarat kemaslahatan bagi masyarakat (Abadi dan Susanto, 2012: 231). 
Fenomena seperti inilah yang oleh Wahid diidentifikasi sebagai pribumisasi Islam. Pribumisasi Islam merupakan suatu proses yang tidak pernah berhenti dalam mengupayakan berkurangnya ketegangan antara "norma agama" dengan "manifestasi budaya". Dalam pribumisasi Islam tergambar mengenai Islam sebagai ajaran yang normatif berasal dari Tuhan diakomodasikan ke dalam kebudayaan yang berasal dari manusia tanpa kehilangan identitasnya masing-masing sehingga tidak ada lagi pemurnian Islam atau menyamakan dengan praktik keagamaan masyarakat muslim di Timur Tengah.

Dalam kaitannya dengan hal ini, Gus Dur menulis:

"Islam mempertimbangkan kebutuhan lokal dalam merumuskan hukumhukum agama tanpa mengubah hukum itu sendiri. Juga bukan berarti meninggalkan norma demi budaya, tetapi agar norma-norma itu menampung kebutuhan-kebutuhan dari budaya dengan menggunakan peluang yang disediakan oleh variasi pemahaman nash dengan tetap memberi peranan kepada ushul fiqh dan qaidah fiqh" (Wahid, 2001: 111).

Menurut Gus Dur, Arabisasi atau proses mengidentifikasi diri dengan budaya Timur Tengah berarti tercerabutnya masyarakat dari akar budaya sendiri. Inti Islam kultural adalah kebutuhan bukan untuk menghindari polarisasi antara agama dan budaya, melainkan menemukan jembatan yang menghubungkan antara agama dan budaya (Naupal, 2012: 292).

Gerakan Islam kultural yang diperkenalkan oleh Gus Dur mendapatkan tantangan dari gerakan Islam fundamental. Dalam dekade belakangan ini, masyarakat Islam Indonesia dilanda dengan apa yang disebut sebagai gerakan "formalisasi syariah" atau lebih tepat sebenarnya gerakan Arabisasi dan puritanisasi. Gerakan puritan yang berujung pada fundamentalisme yang cenderung menafsirkan teks keagamaan secara kaku (rigid) dan literalis (textual) (Kasdi, 2002: 20). Masyarakat Islam Indonesia yang sering diidentikkan dengan masyarakat yang toleran, harmonis, solidaritas sosialnya tinggi, dan tidak terlalu peduli dengan hal-hal yang formalistik, terutama dalam agama, sekarang ini sedang mendapatkan serangan dari kelompok agama yang mengendus melalui partai politik dan gerakan keagamaan.

Islam yang hadir di Indonesia tidak bisa dilepaskan dari dengan tradisi atau budaya Indonesia, sama seperti Islam di Arab Saudi, Arabisme dan Islamisme bergumul sedemikian rupa di kawasan Timur Tengah sehingga kadang-kadang orang sulit membedakan mana yang nilai Islam dan mana yang simbol budaya Arab. Untuk memahami nilai-nilai Islam, para penyiar Islam awal (Walisongo) sebagaimana dijelaskan sebelumnya begitu luwes dan halus dalam menyampaikan pesan-pesan ajaran Islam kepada masyarakat yang heterogen setting 
nilai budayanya. Mereka dengan mudah memasukkan ajaran Islam karena agama tersebut tidak dibawanya dalam bungkus Arab, melainkan dalam racikan dan kemasan bercita rasa budaya lokal. Artinya, masyarakat diberi "bingkisan" yang dibungkus dengan budaya lokal tetapi isinya Islam (Naupal, 2012: 296).

Secara lebih luas, dialektika agama dan budaya lokal tersebut dapat dilihat dalam perspektif sejarah. Agama-agama besar dunia seperti Kristen, Hindu, termasuk Islam karena dalam penyebarannya selalu berhadapan dengan keragaman budaya lokal setempat, sehingga strategi dakwah yang digunakannya seringkali mengakomodasikan budaya lokal tersebut kemudian memberikan spirit keagamaannya.

\section{Tradisi Kultural Islam Jawa}

Islam datang ke bumi Jawa di saat budaya dan tradisi non-Islam terutama Hindu dan Buddha telah mengakar kuat dalam masyarakat Jawa. Karya Clifford Geertz yang berjudul The Religion of Java menjadi rujukan utama hampir seluruh peneliti Barat yang concern mengkaji agama Jawa, seperti Robert W. Hefner (1985 dan 2000), Mark R. Woodward (1998) dan 1989), Niels Mulder (1999), Andrew Beatty (2001), dan Andre Moller (2005), maupun para peneliti Indonesia seperti Abdul Munir Mulkhan (2000), Erni Budiwanti (2000), Muhaimin AG (2001), dan Nur Syam (2004).

Dalam buku The Religion of Java, Geertz mendeskripsikan secara mendalam fenomena agama Jawa, dengan menggunakan tiga tipologi, yakni abangan, santri dan priyayi (Geertz, 1964: 64). Varian abangan dan santri mengacu kepada afiliasi dan komitmen keagamaan, sementara varian priyayi merupakan kategorisasi sosial. Abangan merupakan sebutan bagi mereka yang tidak secara taat menjalankan komitmennya terhadap at uran keagamaan. Santri merupakan sebutan bagi mereka yang memiliki komitmen keagamaan yang diukur berdasarkan tingkat ketaatannya menjalankan serangkaian at uran agama. Priyayi merupakan sebutan bagi mereka yang secara sosial maupun ekonomi dianggap memiliki derajat dan stratifikasi lebih tinggi dibandingkan dengan kebanyakan masyarakat desa di Jawa (Sumbulah, 2012: 52).

Tulisan Geertz banyak memperoleh kritik, terutama model trikotominya yang dirasakan sebagai pemaksaan. Memasukkan priyayi berdampingan dengan santri dan abangan adalah kekeliruan konseptual, sedangkan priyayi adalah kategori sosial. Pendapat yang mirip juga datang dari Hendroprasetyo, di dalam tulisannya tentang "Mengislamkan Orang Jawa". Menurutnya, cara pandang Geertz seperti itu diilhami oleh cara kaum orientalis memandang berbagai tradisi di masyarakat lokal yang dinyatakan sama sekali tidak ada 
kaitannya dengan tradisi besar di luarnya, yakni Islam (Hendroprasetyo, 1993: 75-77). Dalam pandangannya, ada tiga tipologi mengenai Islam di Indonesia, yaitu yang lebih menekankan pada aspek kesejarahan, misalnya anggapan bahwa Islam di Jawa adalah Islam sinkretik, yang disebabkan oleh adanya perbedaan antara Islam di Jawa dengan Islam di tempat lain. Cara pandang lainnya lebih menekankan pada aspek budaya lokal sebagai sebuah struktur otonom yang terlepas dari kaitan historis sehingga yang terlihat ialah simbolsimbol budaya lokal yang termanifestasi di dalam kehidupan masyarakat lokal, termasuk dimensi keberagamaannya. Kemudian, pandangan yang juga dominan ialah penggunaan tolak ukur Islam yang selalu menekankan tradisi Timur Tengah sebagaimana penulis uraikan sebelumnya. Dalam tulisan yang berjudul Menelusuri Dinamika Santri dan Perubahan, dinyatakan bahwa pembagian seperti itu tidak mengacu kepada kenyataan yang sebenarnya disebabkan oleh kesalahan konseptualisasi antara abangan dan santri di satu sisi, dan dengan priyayi di sisi lain (Syam, 2000: 40).

Pada konteks yang hampir sama, Azra menegaskan:

"Dikotomi masyarakat muslim santri yang dikontraskan dengan masyarakat muslim abangan, sebagaimana diungkapkan Geertz dalam Religion of Java, merupakan hasil dari "thick description" yang lebih menekankan pada pandangan bahwa masyarakat keagamaan adalah teks sosial keagamaan daripada entitas lainnya. Hal inilah yang juga dikritik sejarawan Marshall GS Hodgson (the Venture of Islam, vol. 2, 1974) bahwa keunggulan kajian Geertz tentang masyarakat Muslim Jawa ditandai kesalahan sistematik besar, yaitu ketika Geertz mengidentifikasi kaum santri berdasarkan kerangka yang diberikan kaum skripturalis, dan pada saat yang sama, mengelompokkan kaum Muslim lainnya ke dalam kelompok abangan, dan kelompok terakhir ini secara simplistik dia sebut sebagai lebih menganut tradisi Hindu-Buddha daripada Islam" (Azra, 2009: xiii-xiv).

Sebenarnya, dengan menggunakan ketiga tipologi tersebut, Geertz ingin menegaskan bahwa agama Islam di Jawa merupakan kumpulan ekspresi iman, doktrin, ritual dan lain-lain yang dipraktikkan masyarakat sesuai dengan tradisi lokal atau tempat dan waktu seiring dengan perkembangan dan penyebarannya. Dalam konteks inilah, kehadiran Islam di Indonesia khususnya Jawa, mengambil bentuk akomodasi, integrasi, menyerap dan dialog dengan akarakar dan budaya non-Islam, terutama animisme dan hinduisme.

Karena konteks Jawa yang melatari munculnya Islam di Jawa adalah animisme dan hinduisme, maka logis jika "warna dan citarasa" Islam yang berkembang di Jawa juga bernuansa animisme dan hinduisme. Hal ini bisa disaksikan hingga sekarang dalam berbagai sistem ritual Jawa, seperti slametan 
dengan berbagai bentuknya, baik slametan dalam rangkaian acara mantenan, khitanan, bersih desa maupun ekspresi keberagamaan lainnya.

Menggunakan kerangka teoritik Leach tentang polysemy atau multivocality beranggapan bahwa terdapat ambiguit as simbol ritual yang berhubungan dengan variasi dan tingkatan dalam struktur sosial adalah salah satu intelektual yang membenarkan kajian Geertz tentang Islam sinkretis. Di dalam kajiannya tentang Adam and Eve and Vishnu; Syncretism in the Javanese Slametan, menyatakan bahwa slametan adalah inti dari keyakinan agama Jawa popular. Di dalam slametan didapati suatu realitas meskipun mereka berasal dari latar belakang dan penggolongan sosio kultural dan ideologi yang berbeda-beda ternyata bisa menyatu di dalam tradisi ritual slametan. Slametan juga merupakan ekspresi pandangan oposisional tentang Tuhan, wahyu, Islam dan tempat manusia di dalam kosmos. Slametan juga mengiluminasikan cara-cara di mana ritual multivokal dapat dieksploitasi di dalam latar kultural yang berbeda (Beatty, 1996: 271-288).

Ritual slametan juga menjadi salah satu media kelompok abangan dalam mengekspresikan wajah komitmen dan keagamaannya. Varian abangan juga merupakan representasi keagamaan dengan afiliasinya pada animisme. Hal ini bisa dilihat dari ekspresi kelompok ini dalam berbagai ritual slametan, magis, "perdukunan" dan lain-lain. Varian abangan pada umumnya berpusat di desa, tempat dipraktikkannya slametan merupakan inti ritual agama Jawa yang paling popular dan bertahan hingga sekarang. Slametan yang berwujud tingkeban, yakni ritual yang dilaksanakan bagi perempuan yang mencapai usia hamil tujuh bulan ke atas, kelahiran, kematian, bersih desa, sunatan dan lainlain, masih terlihat dominan pada kehidupan masyarakat Jawa, baik yang beragama Islam murni maupun Islam Jawa (sinkretis). Bagi kelompok/varian Jawa, terdapat keyakinan bahwa kehidupan, penderitaan, kematian dan keberkahan, merupakan pemberian roh-roh halus yang harus dipuja melalui berbagai ritual tersebut (Sumbulah, 2012: 53).

Bagi kelompok abangan, slametan diyakini merupakan simbol persembahan terhadap para roh halus, roh leluhur dan lain-lain agar masyarakat terhindar dari bencana dan kejahatan. Fenomena slametan yang dianggap sebagai ritual paling inti dalam masyarakat Jawa ini, bisa disimak pada temuan penelitian Beatty ketika melakukan kajian di Bayu, nama sebuah desa di sebelah selatan kota Banyuwangi. Temuan senada juga bisa dilihat pada hasil penelitian Woodward (1998) tentang masyarakat Jawa di Yogyakarta. Memperkuat tesis Geertz, temuan Hefner pada ekspresi keberagamaan masyarakat Pasuruan juga semakin melengkapinya (Hefner, 1985: 91-128). 
Dalam ritual slametan, semua elemen masyarakat, mulai dari penganut animisme, mistisisme, Islam normatif, kejawen dan hinduisme hadir tanpa membawa serta atribut dan simbol-simbol yang membedakan satu dengan yang lain. Menu slametan biasanya terdiri dari nasi kuning dan apem yang dimakan secara bersama-sama segera setelah dipimpin doa oleh seseorang yang "dituakan". Doa biasanya diawali dengan puji-pujian (șalawat) kepada Nabi Muhammad SAW dan para sahabat, namun kemudian sang pemimpin doa juga memanjatkan doa tersebut kepada para leluhur dan danyang desa (Hefner, 2000: 107). Bahkan, dalam tradisi ritual yang dilakukan oleh kelompok Islam normatif-pun, juga tidak jarang menggunakan tradisi animisme, pra-Islam. Hal ini bisa dilihat pada ritual khitanan di Bayu, setelah ritual penyunatan selesai, dilakukan pemberian tiga warna pada penis si sunat, yakni warna merah yang berasal dari darah ayam, warna kuning dari kunyit dan warna putih dari air kapur. Hal ini dimaksudkan sebagai upaya menolak bala yang mungkin saja bisa datang sewaktu-waktu. Fenomena ritual lainnya yang menjadi media integrasi dari seluruh elemen masyarakat Jawa adalah penyembahan Buyut Cungking di sebuah tempat keramat. Juru kunci keramat yang memimpin upacara penyembahan adalah orang yang fasih membaca doa-doa secara Islam murni (Islam normatif), namun juga fasih melafalkan mantra-mantra Jawa unt uk menghadirkan roh Sang Buyut. Ritual keagamaan ini biasanya juga diawali dengan mantra dan doa tersebut. Ritual-ritual tersebut, tampaknya juga didasari pada konsepsi dasar keyakinan orang Jawa mengenai dunia gaib, bahwa semua perwujudan dalam kehidupan disebabkan oleh makhluk berpikir yang juga memiliki kehendak sendiri (Muchtarom, 2002: 56-57).

Pemandangan-pemandangan paradoksal di atas, menggambarkan betapa Islam di Jawa dibangun dengan tradisi-tradisi pra-Islam, yang membentuk uniformitas dalam diversitas. Mereka yang berasal dari elemen, latar belakang, dan orientasi ideologis yang berbeda, berintegrasi secara kokoh melalui beragam ritual (Sumbulah, 2012: 54). Di sini dapat terlihat bahwa wajah Islam di Jawa merupakan hasil dialog dan dialektika antara Islam dan budaya lokal yang kemudian menampilkan wajah Islam yang khas Jawa yang kemudian disebut Islam Jawa (Muqoyyidin, 2012: 31). Dalam konteks ini pula, tesis Weber bahwa ritus dan mitos merupakan alat integrasi dan harmonisasi kosmis menemukan relevansinya.

\section{E. Simpulan}

Islam Jawa memiliki karakter dan ekspresi keberagamaan yang unik. Hal ini karena penyebaran Islam di Jawa, lebih dominan mengambil bentuk akul- 
turasi, baik yang bersifat menyerap maupun dialogis. Pola akulturasi Islam dan budaya Jawa, di samping bisa dilihat pada ekspresi masyarakat Jawa, juga didukung dengan kekuasaan politik kerajaan Islam Jawa, terutama Mataram yang berhasil mempertemukan Islam Jawa dengan kosmologi Hinduisme dan Buddhisme. Kendati ada fluktuasi relasi Islam dengan budaya Jawa terutama era abad ke-19-an, namun wajah Islam Jawa yang akulturatif terlihat dominan dalam hampir setiap ekspresi keberagamaan masyarakat muslim di wilayah ini sehingga "sinkretisme" dan toleransi agama-agama menjadi satu watak budaya yang khas bagi Islam Jawa.

\section{Daftar Pustaka}

Abadi, Moh. Mashur dan Susanto, Edi. 2012. "Tradisi Ngunya Muslim Pegayaman Bali" dalam Jurnal KARSA, Jurnal Sosial dan Budaya Keislaman edisi Vol. 20, No. 2, Desember 2012.

Abdullah, Amin. 2001. Pendekatan Kajian Islam dalam Studi Agama. Jakarta: Muhammadiyah University Press.

Ahimsa-Putra, Heidy Shri. 1999. Strukturalisme Levy-Strauss, Mitos dan Karya Sastra. Yogyakarta: Bentang Budaya.

al-Humaidy, M. Ali. 2007. "Tradisi Molodhan: Pemaknaan Kontekstual Ritual Agama Masyarakat Pamekasan, Madura" dalam Jurnal ISTIQRO', Jurnal Penelitian Islam Indonesia edisi Vol. 06, No. 01, 2007/1428.

al-Qurtuby, Sumanto. 2003. Arus China-Islam-Jawa: Bongkar Sejarah atas Peranan Tionghoa dalam Penyebaran Agama Islam di Nusantara Abad $X V \& X V I$. Yogyakarta: Inspeal dan Perhimpunan INTI.

Aziz, Asman. 2009. "Multikulturalisme: Wawasan Alternatif Mengelola Kemajemukan Bangsa" dalam Jurnal Titik-Temu, Jurnal Dialog Peradaban edisi Vol. 2, No. 1, Juli-Desember 2009.

Azra, Azyumardi. 2004. Jaringan Ulama Timur Tengah dan Kepulauan Nusantara Abad XVII dan XVIII: Akar Pembaruan Islam Indonesia. Jakarta: Prenada Media. . 2009. "Santri-Abangan Revisited" dalam M. Bambang

Pranowo, Memahami Islam Jawa. Jakarta: Pustaka Alvabet-INSEP.

Beatty, Andrew. 1996. "Adam and Eve and Vishnu: Syncretism in The Javanese Slametan" dalam The Journal of The Royal Antropological Institute 2, 1996.

Bizawie, Zainul Milal. 2003. "Dialektika Tradisi Kultural: Pijakan Historis dan 
Antropologis Pribumisasi Islam" dalam Jurnal Tashwirul Afkar: Jurnal Refleksi Pemikiran Keagamaan dan Kebudayaan edisi No. 14, 2003. Durkheim, Emile. 1995. the Elementary Forms of Religious Life diterj. oleh Karen E Fields. London: The Free Press.

Geertz, Clifford. 1964. The Religion of Java. London: Free Press of Glecoe. Hefner, Robert W. 1985. Hindu Javanese: Tengger Tradition and Islam. Princetone: Princetone University Press. 2000. Islam Pasar Keadilan: Artikulasi Lokal, Kapitalisme dan Demokrasi. Yogyakarta: LKiS.

Hendroprasetyo. 1993. "Mengislamkan Orang Jawa: Antropologi Baru Islam Indonesia" dalam Jurnal Islamika edisi No. 3, 1993.

Hodgson, Marshall GS. 2002. The Venture of Islam: Iman dan Sejarah dalam Peradaban Dunia diterj. oleh Mulyadhi Kartanegara. Jakarta: Paramadina. Kasdi, Abdurrahman. 2002. "Fundamentalisme Islam Timur Tengah: Akar Teologi, Kritik Wacana, dan Politisasi Agama" dalam Jurnal Tashwirul Afkar: Jurnal Refleksi Pemikiran Keagamaan dan Kebudayaan edisi No. $13,2002$.

Kholil, A. 2009. "Agama dan Ritual Slametan: Deskripsi-Antropologis Keberagamaan Masyarakat Jawa” dalam Jurnal el-Harakah edisi Vol. 11, No. 1, Januari-Juni 2009.

Koentjaraningrat. 1985. Pokok-Pokok Antropologi Sosial. Jakarta: Dian Press. 1994. Kebudayaan Jawa. Jakarta: Balai Pustaka.

Kuntowijoyo. 2001. Muslim Tanpa Masjid, Essai-Essai Agama, Budaya, dan Politik dalam Bingkai Strukturalisme Transendental. Bandung: Mizan.

Muchtarom, Zaini. 2002. Islam di Jawa dalam Perspektif Santri dan Abangan. Jakarta: Salemba Diniyah.

Mun'im DZ, Abdul. 2008. "Mengukuhkan Jangkar Islam Nusantara” dalam Jurnal Tashwirul Afkar: Jurnal Refleksi Pemikiran Keagamaan dan Kebudayaan edisi No. 26, 2008.

Muqoyyidin, Andik Wahyun. 2012. "Dialektika Islam dan Budaya Lokal dalam Bidang Sosial Sebagai Salah Satu Wajah Islam Jawa" dalam Jurnal elHarakah edisi Vol. 14, No. 1, Januari-Juni 2012.

Naupal. 2012. "Islam Kultural dan Islam Fundamental di Indonesia" dalam https://icssis.files.wordpress.com/2012/05/1819072011_23.pdf diakses pada 25 Maret 2013.

Oetomo, Dede. 2000. "Memahami Keadaan Sosial-Budaya Daerah”, Makalah “Lokakarya Redaktur Radar Jawa Pos Group” di Surabaya. 
Paisun. 2010. "Dinamika Islam Kultural: Studi atas Dialektika Islam dan Budaya Lokal Madura" dalam Jurnal el-Harakah edisi Vol. 12, No. 2, Juli-Desember 2010.

Ridwan. 2008. "Mistisisme Simbolik dalam Tradisi Islam Jawa" dalam Jurnal Ibda' edisi Vol. 6, No. 1, Januari-Juni 2008.

Ridwan, Nur Khalik. 2004. Agama Borjuis: Kritik atas Nalar Islam Murni. Yogyakarta: ar-Ruzz.

Riyadi, Hendar. 2003. "Respon Muhammadiyah dalam Dialektika Agama" dalam Pikiran Rakyat, 24 Februari 2003.

Roibin. 2010. "Agama dan Budaya: Relasi Konfrontatif atau Kompromistik?" dalam Jurnal Hukum dan Syariah edisi Vol. 1, No. 1, 2010.

Romdhoni, Ali. 2008. "Menemukan Jejak China dan Hindu dalam Islam Jawa; Interpretasi Atas Ilustrasi 'Bledek' dan 'Bulus' di Masjid Agung Demak” dalam Jurnal ISTIQRO', Jurnal Penelitian Islam Indonesia edisi Vol. 07, No. 01, 2008/1429.

Sumbulah, Ummi. 2012. "Islam Jawa dan Akulturasi Budaya: Karakteristik, Variasi dan Ketaatan Ekspresif" dalam Jurnal el-Harakah edisi Vol. 14, No. 1, Januari-Juni 2012.

Suparlan, Parsudi. 1986. "Kebudayaan dan Pembangunan" dalam Media IKA edisi No. 11, Tahun xiv, 1986.

Syam, Nur. 2000. "Menelusuri Dinamika Santri dan Perubahan" dalam Majalah Araaita edisi 40, Tahun XIX, 2000.

Syam, Nur. 2005. Islam Pesisir. Yogyakarta: LKiS. 2007. Madzhab-Madzhab Antropologi. Yogyakarta: LKiS.

Tibi, Bassam. 1991. Islam and The Cultural Accommodation of Social Change diterj. oleh Clare Krojzl. Boulder, San Francisco, and Oxford: Westview Press.

Van Bruinessen, Martin. 2003. "Islam Lokal dan Islam Global di Indonesia" dalam Jurnal Tashwirul Afkar: Jurnal Refleksi Pemikiran Keagamaan dan Kebudayaan edisi No. 14, 2003.

Wahid, Abdurrahman. 2001. Pergulatan Negara, Agama, dan Kebudayaan. Jakarta: Desantara.

Woodward, Mark R. 2000. Islam Jawa: Kesalehan Normatif versus Kebatinan. Yogyakarta: LKiS. 